\title{
Pengaruh Profitabilitas, Struktur Aset, Likuiditas, Dan Pertumbuhan Penjualan Terhadap Struktur Modal Perusahaan Makanan Dan Minuman
}

\author{
Gede Bagus Dwiputra Gunadhi ${ }^{1}$ \\ I Made Pande Dwiana Putra ${ }^{2}$
}

1,2

${ }^{2}$ Fakultas Ekonomi dan Bisnis Universitas Udayana (Unud), Bali, Indonesia e-mail : dwiputrabagus@yahoo.com

\begin{abstract}
ABSTRAK
Tujuan penelitian ini adalah untuk mengetahui pengaruh profitabilitas, struktur aset, likuiditas, dan pertumbuhan penjualan terhadap struktur modal perusahaan makanan dan minuman yang terdaftar di BEI. Penelitian ini dilakukan pada 19 perusahaan makanan dan minuman yang terdaftar di Bursa Efek Indonesia (BEI) tahun 2015-2017 dengan mengakses website www.idx.co.id. Sampel dalam penelitian ini ditentukan dengan menggunakan metode non probability sampling dengan teknik purposive sampling, sehingga sampel akhir yang digunakan dalam penelitian ini berjumlah 15 perusahaan. Metode pengumpulan data yang digunakan, yaitu metode observasi nonpartisipan. Teknik analisis data yang digunakan adalah analisis regresi linier berganda. Hasil dari penelitian ini adalah profitabilitas dan likuiditas memiliki pengaruh yang negatif terhadap struktur modal, sedangkan struktur aset dan pertumbuhan penjualan memiliki pengaruh yang positif terhadap struktur modal.

Kata kunci: Profitabilitas, struktur aset, likuiditas, pertumbuhan penjualan, struktur modal.
\end{abstract}

\begin{abstract}
The purpose of this research is to understand the effect of profitability, asset structure, liquidity, and sales growth on the capital structure of food and beverage companies listed on the IDX. This research was conducted at 19 food and beverage companies listed on the Indonesia Stock Exchange (IDX) in 2015-2017 by accessing the website www.idx.co.id. The sample used in this study was determined using a non probability sampling method by used purposive sampling technique, so the final sample used in this study amounted to 15 companies. The data collection method used is the nonparticipant observation method. The data analysis technique used is multiple linear regression analysis. The results of this study are that profitability and liquidity have a negative influence on the capital structure, while the asset structure and sales growth have a positive influence on capital structure.

Keywords: Profitability, asset structure, liquidit, sales growth, capital structure.
\end{abstract}

\section{PENDAHULUAN}

Modal merupakan instrumen yang sangat penting dalam mendukung keberlangsungan dari perusahaan. Modal (Capital) adalah dana yg digunakan untuk membiayai pengadaan aset dan operasional suatu perusahaan. Sumber modal dari suatu perusahaan dapat berasal dari internal atau internal financing yaitu modal yang berasal dari dalam perusahaan itu sendiri dan eksternal atau 
external financing. Selain berasal dari dalam perusahaan modal juga dapat berasal dari eksternal atau sumber modal dari luar perusahaan yang berasal dari para kreditur dan pemilik, stake holder atau pengambil bagian di dalam perusahaan.

Perusahaan pada sektor industri yang mempunyai laju pertumbuhan yang tinggi harus menyediakan modal yang cukup untuk pembukaan bisnis maupun pengembangan bisnisnya. Perusahaan makanan dan minuman merupakan salah satu sektor industri yang terus mengalami pertumbuhan. Meningkatnya permintaan konsumen terhadap barang kebutuhan sehari-hari berupa makanan dan minuman, maka meningkat pula kebutuhan perusahaan akan modal perusahaan itu sendiri.

Perusahaan makanan dan minuman merupakan perusahaan yang produknya sangat dibutuhkan masyarakat sehingga prospeknya menguntungkan baik masa sekarang maupun masa yang akan datang. Hal ini didukung juga dengan jumlah penduduk Indonesia yang terus meningkat, sehingga permintaan terhadap kebutuhan makanan dan minuman menjadi semakin meningkat. Dapat dilihat dalam Gambar 1 bahwa pertumbuhan industri sektor makanan dan minuman dari tahun 2015-2017 terus menunjukkan adanya pertumbuhan yang positif. 


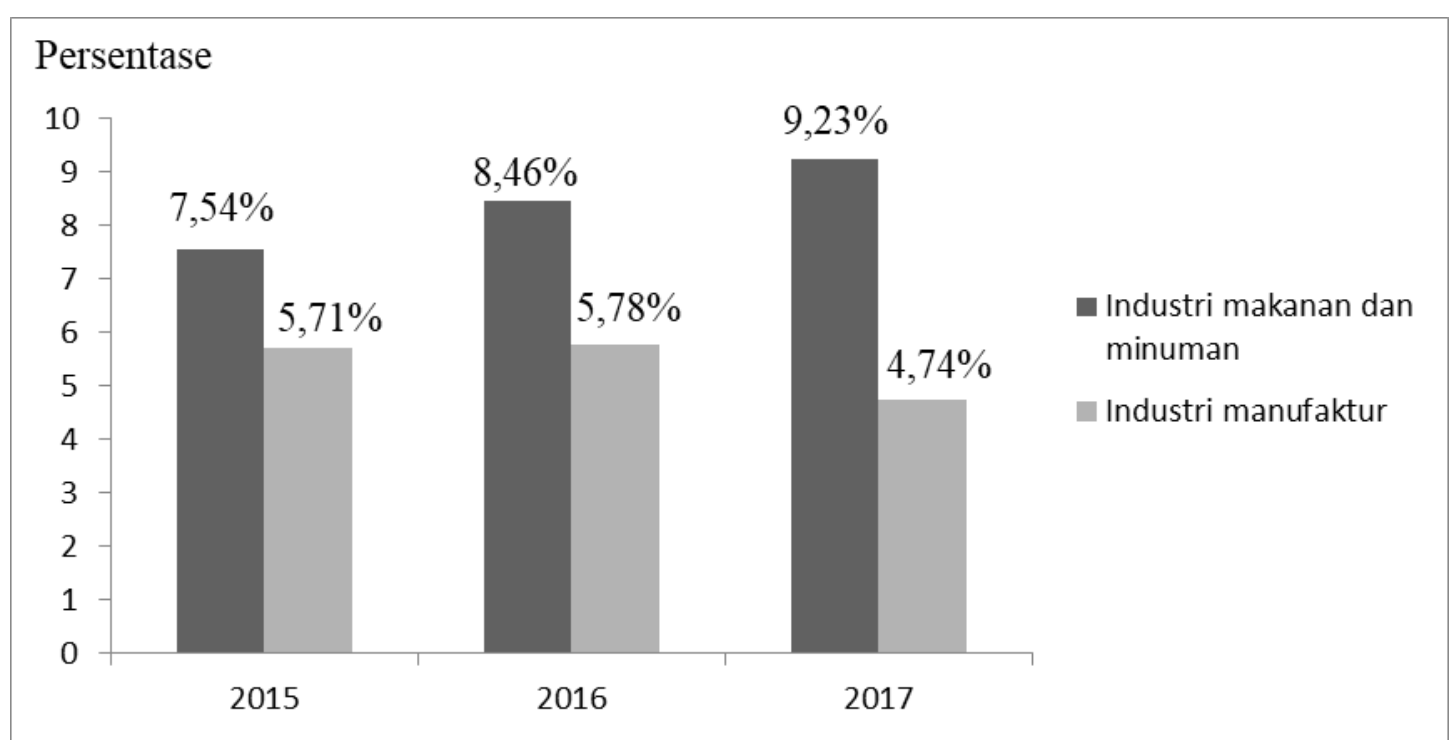

Gambar 1. Pertumbuhan Industri Makanan dan Minuman dan Industri Manufaktur di Indonesia

Sumber: Kementrian Perindustrian RI, 2018

Perusahaan pada sektor industri yang terus mengalami pertumbuhan cenderung intensif dalam modal guna pengembangan produk dan ekspansi pangsa pasarnya. Semakin berkembangnya perusahaan makanan dan minuman, maka skala produksi serta volume penjualan juga akan mengalami peningkatan. Peningkatan-peningkatan yang terjadi akibat perkembangan yang pesat akan mempengaruhi struktur modal dari perusahaan tersebut karena dalam proses pengembangan perusahaan diperlukan modal yang terbilang cukup besar.

Struktur modal bisa dikatakan sebagai sumber pembiayaan perusahaan yang bersifat permanen yang terdiri dari hutang jangka panjang, saham preferen dan ekuitas pemegang saham (Mufidah, 2012 dalam Puspawardhani, 2011). Setiap perusahaan memiliki pilihan yang berbeda dalam menentukan pembiayaan modal perusahaan. Perbedaan pilihan tersebut berpengaruh pada struktur modal perusahaan (Saleem et al., 2013). Pesatnya pertumbuhan perusahaan serta 
Gede Bagus Dwiputra Gunadhi dan I Made Pande Dwiana Putra. Pengaruh ...

semakin ketatnya persaingan di sektor industri makanan dan minuman, menyebabkan perusahaan membutuhkan pendanaan yang besar, baik dalam hal penambahan investasi dalam aset tetap maupun untuk kegiatan operasional yang akan berdampak pada struktur modal perusahaan. Berikut ini disajikan data struktur modal pada perusahaan makanan dan minuman yang terdaftar di Bursa Efek Indonesia periode 2015-2017 yang diukur dengan Debt to Equity Ratio.

Tabel 1.

Debt to Equity pada Perusahaan Makanan dan Minuman Tahun 2015-2017

\begin{tabular}{lcccc}
\multicolumn{4}{c}{ Tahun 2015-2017 } & DER (\%) \\
No. & Nama & 2015 & 2016 & 2017 \\
\hline
\end{tabular}

1. PT. Akasha Wira International Tbk.

$99 \quad 100 \quad 99$

2. PT. Delta Djakarta Tbk.

$22 \quad 18 \quad 17$

3. PT. Indofood CBP Sukses Makmur Tbk.

$62 \quad 56 \quad 56$

4. PT. Indofood Sukses Makmur Tbk.

$\begin{array}{lrr}113 & 87 & 88\end{array}$

5. PT. Mayora Indah Tbk.

6. PT. Multi Bintang Indonesia Tbk.

$118 \quad 106 \quad 103$

7. PT. Nippon Indosari Corporindo Tbk.

PT. Prashida Aneka Niaga Tbk.

9. PT. Sekar Bumi Tbk.

$91 \quad 133 \quad 131$

10. PT. Sekar Laut Tbk.

PT Tiga Pilar Sejahtera Food Tbk.

12. PT. Tri Banyan Tirta Tbk.

$128 \quad 117 \quad 156$

13. PT. Siantar Top Tbk.

$133 \quad 142 \quad 165$

14. PT. Ultrajaya Milk and Trading Company Tbk.

15. PT. Wilmar Cahaya Indonesia Tbk.

$90 \quad 100 \quad 69$

$27 \quad 21 \quad 23$

$\begin{array}{lll}132 & 61 & 54\end{array}$

Sumber: idx.co.id, 2018

Rata-rata

106

98

89

Berdasarkan Tabel 1 mengenai debt to equity ratio perusahaan makanan dan minuman di BEI tahun 2015-2017, struktur modal beberapa perusahaan menunjukkan adanya fluktuasi. Jika dilihat dari rata-rata DER perusahaan makanan dan minuman pada tahun 2015-2017 menunjukkan adanya penurunan secara berturut-turut, yang berarti bahwa rata-rata perusahaan mengurangi komposisi penggunaan hutang dalam menentukan struktur modal perusahaan. 
Fenomena ini menunjukkan bahwa ada beberapa faktor yang memengaruhi peningkatan dan penurunan struktur modal dibalik pertumbuhan industri yang terus mengalami peningkatan dan membutuhkan pendanaan yang besar.

Menurut Keown dalam Kanita (2014), perusahaan harus memahami komponen-komponen utama struktur modal. Struktur modal yang optimal adalah struktur modal perusahaan yang akan memaksimalkan harga sahamnya. Variabel yang digunakan dalam penelitian ini yaitu profitabilitas, struktur aset, likuiditas, dan pertumbuhan penjualan, karena penelitian-penelitian terdahulu mengenai pengaruh variabel-variabel tersebut terhadap struktur modal menunjukkan perbedaan hasil penelitian, maka penelitian ini ingin mengkonfirmasi teori-teori dan penelitian-penelitian terdahulu.

Variabel pertama dalam penelitian ini yaitu profitabilitas. Menurut Mamduh (2008), profitabilitas merupakan kemampuan suatu perusahaan dalam menghasilkan laba atau profit. Perusahaan dengan profitabilitas yang tinggi cenderung menggunakan pendanaan dari dalam perusahaan atau internal financing. Perusahaan cenderung menekan penggunaan hutang dengan menyediakan laba ditahan yang lebih banyak (Ryanni \& Farah, 2014).

Struktur aset merupakan variabel kedua dalam penelitian ini yang mempengaruhi struktur modal. Menurut Weston \& Copeland (2008), perusahaanperusahaan dengan aset yang tinggi dan digunakan untuk agunan hutang dapat menggunakan hutang dalam jumlah yang besar. Ketika perusahaan memiliki aset yang banyak dan bernilai tinggi, perusahaan dapat memanfaatkan aset tersebut untuk mendapatkan modal tambahan dari luar perusahaan atau external financing 
yaitu melalui hutang. Aset yang dimiliki oleh perusahaan dapat digunakan sebagai jaminan bagi perusahaan untuk mendapatkan modal tambahan. Aset yang bernilai tinggi sebagai jaminan, maka jumlah tambahan modal yang akan didapat oleh perusahaan juga akan berjumlah besar (Sitanggang, 2013).

Variabel ketiga dalam penelitian ini yaitu likuiditas. Menurut Sartono (2012), dalam menentukan struktur modal, likuiditas merupakan salah satu faktor yang wajib dipertimbangkan. Bagaimana perusahaan dalam memenuhi kewajiban keuangan yang dimiliki perusahaan tersebut merupakan yang dimaksud dengan likuiditas (Munawir, 2008). Berdasarkan pecking order theory, perusahaan dengan likuiditas tinggi cenderung menggunakan pendanaan internal daripada pendanaan eksternal. Berdasarkan teori ini, perusahaan lebih memilih pendanaan internal karena mempertimbangkan keamanan keadaan keuangan perusahaan. Selain pertimbangan keamanan keuangan perusahaan, penggunaan pendanaan internal juga menghindari pembengkakan pada biaya modal perusahaan (Husnan, Hanafi, \& Munandar, 2014).

Pertumbuhan penjualan merupakan variabel keempat pada penelitian ini. Menurut Brigham \& Housten (2011), kestabilan penjualan perusahaan dapat berdampak pada jumlah pinjaman yang dapat diperoleh oleh perusahaan. Semakin baik tingkat penjualan perusahaan maka jumlah pinjaman yang didapat akan lebih besar juga. Struktur modal perusahaan akan berubah tergantung dari perkembangan tingkat penjualan perusahaan. Tingginya pertumbuhan perusahaan menyebabkan perusahaan akan memerlukan modal yang lebih besar sehingga perlunya tambahan modal dari eksternal. 
ISSN: 2302-8556

E-Jurnal Akuntansi

Vol.28.1.Juli (2019): 641-668

Myers and Majluf mengemukakan sebuah teori yaitu Pecking Order Theory yang mendukung teori struktur modal. Teori ini memberikan penjelasan mengenai alasan perusahaan ketika membuat keputusan dalaam pendanaan sesuai dengan hirarki sumber dana yang dikehendaki oleh perusahaan. Pecking Order Theory menyebutkan perusahaan cenderung lebih memanfaatkan pendanaan internalnya terlebih dahulu daripada menggunakan pendanaan eksternal. Pendanaan eksternal menjadi alternatif ketika perusahan tidak memiliki dana internal yang cukup. Dana eksternal lebih disukai dalam bentuk hutang karena pertimbangan biaya emisi hutang jangka panjang yang lebih murah dibanding dengan biaya emisi saham.

Teori trade-off muncul karena penggabungan teori Modigliani-Miller yang memasukkan biaya kebangrutan dan biaya agensi. Menurut Mamduh (2008), teori trade-off mempunyai implikasi bahwa manajer akan berfikir dalam kerangka trade-off antara penghematan pajak dan biaya kebangkrutan dalam penentuan struktur modal. Berdasarkan Trade-off theory, hutang dianggap sumber pendanaan eksternal yang paling murah, sehingga perusahaan akan menggunakan hutang dalam pencapaian tujuan jangka panjangnya (Wijaya, 2014).

Struktur modal perusahaan merupakan keputusan pendanaan yang dilakukan oleh manajer keuangan yang berkaitan dengan bagaimana membiayai keputusan investasi yang akan dilakukan perusahaan (Wiagustini, 2014). Menurut Ambarwati (2010), struktur modal merupakan suatu kombinasi atau perimbangan antara hutang dan modal sendiri yang digunakan perusahaan untuk merencanakan 
mendapatkan modal. Masnoon, Maryam. \& Abiha (2014) kombinasi dari total hutang dan ekuitas yang dapat meminimalkan biaya modal perusahaan dapat menghasilkan struktur modal yang dianggap optimal. Teori trade-off mengasumsikan bahwa struktur modal yang optimal dapat divisualisasikan sebagai trade-off antara keuntungan pembiayaan hutang dan biaya pembiayaan hutang (Acaravci, 2015).

Profitabilitas suatu perusahaan mencerminkan tingkat efektifitas yang dicapai oleh suatu operasional perusahaan. Profitabilitas menunjukan bagaimana perusahaan dapat mengelola operasional dan sumber daya perusahaan yang kemudian dapat menghasilkan laba yang diharapkan. Profitabilitas yang tinggi cenderung untuk memanfaatkan sumber dana internal berupa laba ditahan terlebih dahulu dan menggunakan pendanaan eksternal yang relatif rendah (Ryanni \& Farah, 2014).

Menurut Sari dan Haryanto (2013: 6) dalam Nofriani (2015), struktur aset dapat digunakan oleh perusahaan sebagai jaminan untuk mendapatkan utang. Cara mengukut struktur aset adalah dengan melakukan perbandingkat antara aset tetap dan total aset. Struktur aset menunjukkan aset yang digunakan untuk aktivitas operasional perusahaan. Perusahaan yang memiliki aset tetap yang banyak dan bernilai tinggi, perusahaan dapat memanfaatkan aset tersebut untuk mendapatkan modal tambahan dari luar perusahaan atau external financing yaitu melalui hutang (Sitanggang, 2013).

Setiap perusahaan tentunya memiliki kewajiban finansial yang harus dipenuhi. Kemampuan suatu perusahaan dalam memenuhi kewajiban finansial 
tersebut dimaksud dengan likuiditas. Perusahaan yang memiliki likuiditas yang baik akan meningkatkan kepercayaan pihak eksternal terhadap perusahaan. Likuiditas perusahaan yang tinggi menunjukkan bahwa perusahaan tersebut memiliki keuangan internal yang memadai untuk memenuhi kewajiban yang bersifat jangka pendeknya.

Pertumbuhan penjualan adalah kenaikan jumlah penjualan dari tahun ke tahun atau dari waktu ke waktu (Kennedy, 2010). Semakin tinggi tingkat pertumbuhan penjualan suatu perusahaan maka perusahaan tersebut semakin berhasil dalam menjalankan strateginya. Manajemen perusahaan dapat dinilai kinerjanya dengan melihat penjualan yang dihasilkan. Dengan penjualan yang terus bertumbuh maka manajemen akan memiliki nilai positif dan dianggap telah bekerja dengan baik. Manajemen dianggap memiliki prospek yang bagus yang kemudian berpengaruh pada meningkatnya penjualan dan semakin baiknya struktur modal perusahaan.

Brigham \& Housten (2011) perusahaan yang memiliki rasio profitabilitas yang tinggi, cenderung menghindari penggunaan pendanaan eksternal atau utang. Pecking Order Theory menyatakan perusahaan dengan kondisi keuangan yang tergolong baik lebih memilih internal funding. Perusahaan cenderung lebih memanfaatkan pendanaan internalnya terlebih dahulu daripada menggunakan pendanaan eksternal. Pendanaan eksternal menjadi alternatif ketika perusahan tidak memiliki dana internal yang cukup.

Penelitian Windayu (2016) menemukan bahwa profitabilitas berpengaruh negatif pada struktur modal. Terdapat hasil penelitian serupa pada penelitian dari 
Gede Bagus Dwiputra Gunadhi dan I Made Pande Dwiana Putra. Pengaruh ...

Mohamadzadeh, Arabi, \& Salamzadeh (2013), Gamaliel \& Sudjarni (2012), Sarlija \& Harc (2016), Çekrezi (2013). Dari uraian tersebut, maka hipotesis yang dapat dikembangkan adalah:

$\mathrm{H}_{1}$ : Profitabilitas berpengaruh negatif terhadap struktur modal perusahaan.

Perusahaan dengan jumlah aset tetap yang banyak cenderung menggunakan hutang dalam struktur permodalan perusahaan karena aset yang terdapat di perusahaan dapat dijadikan jaminan kepada kreditur saat memberikan hutang. Peluang suatu perusahaan untuk memperoleh dan menggunakan hutang semakin besar apabila struktur aset yang dimiliki suatu perusahaan dalam jumlah besar yang nantinya dipergunakan sebagai jaminan utang tersebut. Kreditur akan lebih yakin terhadap perusahaan yang mempunyai aset tetap yang besar karena apabila terjadi kegagalan pembayaran maka perusahaan dapat menyelesaikan kewajibannya kepada kreditur dengan jaminan asetnya tersebut. Dengan demikian, dapat diprediksikan struktur aset memiliki hubungan yang positif terhadap struktur modal.

Adapun beberapa penilitian yang mendukung teori tersebut, yaitu penelitian dari Liem (2013) menyatakan bahwa tangibility berpengaruh secara positif terhadap struktur modal. Apabila variabel tangibility mengalami kenaikan, maka variabel utang juga mengalami kenaikan dan begitu pula sebaliknya. Dharmadi \& Putri (2018) dan Pattweekongka (2014) juga mengemukakan bahwa struktur aset memiliki pengaruh positif terhadap struktur modal. Dari uraian tersebut, maka hipotesis yang dapat dikembangkan adalah:

$\mathrm{H}_{2}$ : Struktur aset berpengaruh positif terhadap struktur modal perusahaan. 
Likuiditas adalah bagaimana kemampuan perusahaan dalam memenuhi kewajiban finansial yang dimiliki oleh perusahaan tersebut (Wiagustini, 2014). Berdasarkan Pecking Order Theory menyebutkan perusahaan cenderung lebih memanfaatkan pendanaan internalnya terlebih dahulu daripada menggunakan pendanaan eksternal. Pendanaan eksternal menjadi alternatif ketika perusahan tidak memiliki dana internal yang cukup. Tingkat likuiditas yang tinggi menyebabkan perusahaan akan menghindari penggunaan pendanaan eksternal. Mardinawati (2011) dalam penelitiannya menemukan bahwa kemampuan perusahaan dalam memenuhi kewajiban jangka pendeknya dapat dilihat dari likuiditasnya yang tinggi. Ketika perusahaan memiliki likuiditas yang tinggi maka dapat mengurangi total hutang yang dimiliki yang berdampak pada struktur modal yang kecil. Penelitian yang dilakukan oleh Shanka (2015) serta Juliantika \& Dewi (2016), menemukan bahwa likuiditas memiliki pengaruh yang negatif pada struktur modal.

$\mathrm{H}_{3}$ : Likuiditas berpengaruh negatif terhadap struktur modal perusahaan.

Udayani \& Suaryana (2013) dalam penelitiannya menemukan bahwa, perusahaan dengan penjualan yang tinggi memerlukan modal yang lebih besar serta memiliki kempatan untuk mendapatkan pendanaan dari eksternal lebih tinggi dan berdampak pada struktur modal yang meningkat. Perusahaan dengan tingkat pertumbuhan penjualan yang tinggi menunjukkan prospek perusahaan tersebut semakin bagus yang akan menarik perhatian pihak luar untuk menanamkan modalnya. Trade-off theory menyarankan perusahaan untuk menggunakan hutang 
dalam pencapaian tujuan jangka panjang karena utang dianggap sumber pendanaan eksternal yang paling murah (Wijaya \& Utama., 2014).

Berdasarkan penelitian Khairin \& Harto (2014), Angelina \& Mustanda (2016), Erosvitha \& Wirawati (2016), dan Halim \& Widanaputra (2018), ditemukan adanya pengaruh positif antara hubungan tingkat pertumbuhan penjualan terhadap struktur modal.

$\mathrm{H}_{4}$ : Pertumbuhan penjualan berpengaruh positif terhadap struktur modal perusahaan.

\section{METODE PENELITIAN}

BEI atau Bursa Efek Indonesia merupakan lokasi yang dipilih untuk penelitian ini. Dalam BEI terdapat berbagai sector perusahaan dengan lebih dari 300 perusahaan yang terdaftar. Penelitian ini secara spesifik melakukan penelitian pada perusahaan makanan dan minuman yang terdaftar di BEI. Perusahaan makanan dan minuman yang dipilih haruslah terdaftar di BEI selama periode 2015-2017. Cara untuk mengumpulkan data adalah dengan mengakses website www.idx.co.id. Obyek dari penelitian ini adalah struktur modal yang terdapat pada laporan keuangan dan laporan tahunan perusahaan makanan dan minuman yang terdaftar di BEI tahun 2015-2017 dengan mengakses website www.idx.co.id Variabel-variabel pada penelitian ini yaitu struktur modal, profitabilitas, struktur aset, likuiditas, dan pertumbuhan penjulan. Variabel terikat dalam penelitian ini adalah struktur modal (Y). Variabel bebas dalam penelitian ini adalah profitabilitas $\left(\mathrm{X}_{1}\right)$, struktur aset $\left(\mathrm{X}_{2}\right)$, likuiditas $\left(\mathrm{X}_{3}\right)$, dan pertumbuhan penjualan $\left(\mathrm{X}_{4}\right)$. Struktur modal pada penelitian ini diukur dengan menggunakan 
debt to equity ratio (DER). Menurut Wiagustini (2014), untuk mengukur debt to equity ratio (DER) adalah:

$$
\mathrm{DER}=\frac{\text { total liabilities }}{\text { total } \text { equity }} \times 100 \%
$$

Profitabilitas diukur dengan return on assets (ROA). Return on assets Menurut Wiagustini (2014), perhitungan profitabilitas adalah sebagai berikut:

$$
\mathrm{ROA}=\frac{\text { laba setelah pajak }}{\text { total aset }} \times 100 \%
$$

Struktur aset adalah jaminaan berupa aaset diukur dengan membandingkan antara aset tetap dengan total aset (Nofriani, 2015). Menurut (Bambang, 2013), struktur aset dapat dihitung dengan menggunakan rumus sebagai berikut:

Struktur Aset $=\frac{\text { Total Aset Tetap }}{\text { Total Aset }} \times 100 \%$

Likuiditas pada penelitian ini dihitung dengan quickt ratio. Hampir sama dengan current ratio, namun aset lancar harus dikurangkan dengan jumlah persediaan (inventory). Persediaan adalah aset yang paling tidak likuid dan bila terjadi likuidasi, maka persediaan merupakan aset yang paling sering menderita kerugian (Moeljadi \& Supriyati., 2014). Menurut Kasmir (2010), rumus untuk mengukur likuiditas dengan quick ratio adalah:

Quick ratio $=\frac{\text { current asset -inventory }}{\text { current liablitiy }} \times 100 \%$

Pertumbuhan penjualan perusahaan pada penelitian ini yaitu perbandingan antara penjualan periode $\mathrm{t}$ dikurangi penjualan periode $\mathrm{t}-1$ dengan penjualan $\mathrm{t}-1$ perusahaan dari tahun 2015-2017. Menurut Harahap (2016), pertumbuhan penjualan dinyatakan dalam persentase serta dapat dinyatakan dalam rumus sebagai berikut : 
Pertumbuhan Penjualan $=\frac{\text { penjualan }(\mathrm{t})-\text { penjualan }(\mathrm{t}-1)}{\text { penjualan }(\mathrm{t}-1)} \times 100 \%$

Populasi yang digunakan dalam penelitian ini adalah seluruh perusahaan makanan dan minuman yang terdaftar di Bursa Efek Indonesia tahun 2015-2017 yang berjumlah 19 perusahaan. Metode sampling yang digunakan dalam penelitian ini yaitu non probability sampling dengan teknik purposive sampling. Kriteria-kriteria penentuan sampel penelitian ini adalah perusahaan makanan dan minuman yang terdaftar di BEI yang menerbitkan laporan tahunan (annual report) dan laporan keuangan, serta listing secara berurut-turut selama tahun 2015-2017. Berdasarkan hasil seleksi, jumlah sampel yang diteliti yaitu berjumlah 15 perusahaan. Penelitian yang menggunakan analisis data statistik, jumlah sampel paling minimum adalah 30 . Berdasarkan syarat tersebut, maka periode penelitian diperpanjang menjadi tiga tahun sehingga total pengamatan dalam penelitian ini berjumlah 45 .

Penelitian ini menggunakan jenis data kuantitatif. Data kuantitatif dalam penelitian ini adalah angka-angka dalam laporan keuangan tahunan perusahaan makanan dan minuman di Bursa Efek Indonesia tahun 2015-2017. Data sekunder yang digunakan dalam penelitian ini diperoleh dari laporan keuangan dan laporan tahunan perusahaan makanan dan minuman yang terdaftar di Bursa Efek Indonesia tahun 2015-2017 dengan mengakses website www.idx.co.id

Metode pengumpulan data yang digunakan yaitu metode oservasi nonpartisipan. Pada penelitian ini pengamatan bersumber dari Bursa Efek Indonesia yaitu melalui www.idx.co.id, hasil-hasil penelitian terdahulu dan berbagai jurnal yang berkaitan dengan penelitian ini. Analisis data yaitu kegiatan 
yang dilakukan untuk merubah data hasil dari penelitian menjadi informasi yang nantinya bisa dipergunakan dalam mengambil kesimpulan.Teknik analisis data yang digunakan adalah analisis regresi linier berganda.

\section{HASIL DAN PEMBAHASAN}

Hasil analisis statistik deskriptif dalam penelitian ini ditunjukan pada Tabel 2 berikut.

Tabel 2.

Hasil Statistik Deskriptif

\begin{tabular}{|c|c|c|c|c|c|}
\hline & $\mathrm{N}$ & Minimum & Maksimum & Mean & Std. Deviation \\
\hline Struktur Modal & 45 & 17,00 & 177,00 & 97,911 & 44,2841 \\
\hline Profitabilitas & 45 & $-9,71$ & 52,67 & 9,1887 & 11,20755 \\
\hline Struktur Aset & 45 & 6,71 & 93,93 & 39,5500 & 18,54999 \\
\hline Likuiditas & 45 & 33,92 & 735,74 & 162,4846 & 147,97019 \\
\hline Pertumbuhan Penjualan & 45 & $-24,83$ & 50,02 & 6,4979 & 13,21557 \\
\hline
\end{tabular}

Sumber: Data diolah,2018

Variabel struktur modal (Y) memiliki nilai terendah (minimum) sebesar 17 persen, nilai tertinggi (maksimum) sebesar 177 persen, dan nilai rata-rata data sebesar 97,911 persen. Nilai rata-rata data dari variabel Y adalah 97,911 persen dengan deviasi standar variabel struktur modal adalah sebesar 44,2841. Variabel profitabilitas $\left(\mathrm{X}_{1}\right)$ memiliki nilai terendah (minimum) sebesar $-9,71$ persen, nilai tertinggi (maksimum) sebesar 52,67 persen, dan nilai rata-rata data sebesar 9,1887 persen. Deviasi standar variabel profitablitas adalah sebesar 11,20755. Variabel struktur aset $\left(\mathrm{X}_{2}\right)$ memiliki nilai terendah (minimum) sebesar 6,71 persen, nilai tertinggi (maksimum) sebesar 93,93 persen, dan nilai rata-rata data sebesar 39,5500 persen . Deviasi standar variabel struktur aset adalah sebesar 18,54999. Variabel likuiditas $\left(\mathrm{X}_{3}\right)$ memiliki nilai terendah (minimum) sebesar 33,92 persen, nilai tertinggi (maksimum) sebesar 735,74 persen, dan nilai rata-rata data sebesar 
Gede Bagus Dwiputra Gunadhi dan I Made Pande Dwiana Putra. Pengaruh ...

162,4846 persen. Deviasi standar variabel likuiditas adalah sebesar 172,97019. Variabel pertumbuhan penjualan $\left(\mathrm{X}_{4}\right)$ memiliki nilai terendah (minimum) sebesar $-24,83$ persen, nilai tertinggi (maksimum) sebesar 50,02 persen, dan nilai rata-rata data sebesar 6,4979 persen. Deviasi standar variabel pertumbuhan penjualan adalah sebesar 13,21557. Hasil dari uji normalitas disajikan pada Tabel 3 sebagai berikut.

Tabel 3.

Hasil Uji Normalitas

\begin{tabular}{cc}
\hline & Unstandardized Residual \\
\hline $\mathrm{N}$ & 45 \\
Kolmogorov-Smirnov $Z$ & 0,660 \\
Asymp.Sig.(2-tailed) & 0,776 \\
\hline Sumber: Data diolah,2018
\end{tabular}

Berdasarkan hasil analisis uji normalitas, didapat nilai signifikansi sebesar 0,776. Karena nilai signifikansi uji Kolmogorov-Smirnov lebih dari 0,05 maka dapat disimpulkan bahwa model persamaan regresi tersebut berdistribusi normal.

Model regresi yang baik adalah tidak terjadi korelasi diantara variabel bebas. Jika nilai tolerance lebih dari $10 \%$ atau VIF Kurang dari 10, maka dapat dikatakan model telah bebas dari multikolinearitas. Hasil uji multikolinieritas disajikan pada Tabel 4 seperti berikut.

Tabel 4. Hasil Uji Multikoleniaritas

\begin{tabular}{lrc}
\hline \multicolumn{1}{c}{ Variabel } & Tolerance & \multicolumn{1}{c}{ VIF } \\
\hline Profitabilitas $\left(\mathrm{X}_{1}\right)$ & 0,950 & 1,053 \\
Struktur Aset $\left(\mathrm{X}_{2}\right)$ & 0,834 & 1,199 \\
Likuiditas $\left(\mathrm{X}_{3}\right)$ & 0,799 & 1,251 \\
Pertumbuhan penjualan $\left(\mathrm{X}_{4}\right)$ & 0,915 & 1,093 \\
\hline Sumber: Data diolah,2018 & &
\end{tabular}

Setelah melakukan uji multikolinearitas didapatkan hasil bahwa variabel $\mathrm{X}_{1}$, $\mathrm{X}_{2}, \mathrm{X}_{3}$, dan $\mathrm{X}_{4}$ masing masing memiliki nilai tolerance yang melebihi 10 persen 
dan masing-masing variaabel memiliki nilai VIF kurang dari 10 yang berarti model persamaan dalam penelitian ini terbebas dari masalah multikolinearitas.

Hasil uji autokorelasi pada penelitian ini menunjukan bahwa besarnya nilai Durbin Watson sebesar 1,911. Nilai D-W menurut tabel dengan $\mathrm{n}=45$ dan $\mathrm{k}=4$ didapat nilai $\mathrm{d}_{\mathrm{L}}=1,3357$ dan nilai $\mathrm{d}_{\mathrm{u}}=1,7200$. Oleh karena nilai $\mathrm{d}_{\mathrm{u}}<\mathrm{dw}<4-\mathrm{d}_{\mathrm{u}}$ $(1,7200<1,911<2,280)$, maka dapat disimpulkan tidak terdapat autokorelasi antar residual.

Model regresi yang baik adalah yang tidak mengandung gejala heteroskedastisitas atau mempunyai varians yang homogen. Jika variabel bebas yang diteliti tidak mempunyai pengaruh signifikan atau nilai signifikansinya lebih dari 0,05 terhadap nilai absolute residual, berarti model regresi tidak mengandung gejala heteroskedastisitas. Hasil pengujian heteroskedastisitas disajikan pada Tabel 5 berikut :

Tabel 5.

Hasil Uji Heteroskedastisitas

\begin{tabular}{|c|c|c|c|c|c|}
\hline \multirow[t]{2}{*}{ Model } & \multicolumn{2}{|c|}{$\begin{array}{l}\text { Unstandardized } \\
\text { Coefficients }\end{array}$} & \multirow{2}{*}{$\begin{array}{c}\text { Standardized } \\
\text { Coefficients } \\
\text { Beta } \\
\end{array}$} & \multirow[b]{2}{*}{$\mathrm{T}$} & \multirow[b]{2}{*}{ Sig. } \\
\hline & B & Std. Error & & & \\
\hline (Constant) & 0,258 & 0,018 & & 14,134 & 0,000 \\
\hline $\mathrm{ROA}$ & $-0,003$ & 0,012 & $-0,042$ & $-0,276$ & 0,784 \\
\hline Struktur Aset & 0,033 & 0,017 & 0,323 & 1,970 & 0,056 \\
\hline Likuiditas & 0,026 & 0,020 & 0,221 & 1,320 & 0,194 \\
\hline Pertumbuhan & 0,006 & 0,016 & 0,061 & 0,390 & 0,698 \\
\hline Penjualan & & & & & \\
\hline
\end{tabular}

Setelah melakukan uji heteroskedastisitas didapatkan hasil bahwa $\mathrm{X}_{1}, \mathrm{X}_{2}$, $\mathrm{X}_{3}$, dan $\mathrm{X}_{4}$ masing-masing memiliki nilai signifikansi melebihi 0,05 yang berarti tidak terdapat pengaruh antara variabel bebas terhadap absolute residual maka model yang digunakan tidak terdapat masalah heteroskedastisitas. 
Setelah terpenuhinya semua syarat dari uji asumsi klasik, uji selanjutnya adalah analisi linier berganda dengan hasil sebagai berikut.

\section{Tabel 6.}

Hasil Analisis Regresi Linier Berganda

\begin{tabular}{llccccc}
\hline Model & \multicolumn{2}{c}{ Unstandardized } \\
& Coefficients & Standardized & & \\
& Coefficients & & \\
& & B & Std. Error & Beta & T & Sig. \\
\hline 1 & (Constant) & $-0,029$ & 0,108 & & $-0,268$ & 0,790 \\
& Profitabilitas $\left(\mathrm{X}_{1}\right)$ & $-0,148$ & 0,072 & $-0,220$ & $-2,057$ & 0,046 \\
& Struktur Aset $\left(\mathrm{X}_{2}\right)$ & 0,330 & 0,099 & 0,380 & 3,326 & 0,002 \\
& Likuiditas $\left(\mathrm{X}_{3}\right)$ & $-0,321$ & 0,117 & $-0,320$ & $-2,739$ & 0,009 \\
& Pertumbuhan penjualan $\left(\mathrm{X}_{4}\right)$ & 0,223 & 0,097 & 0,252 & 2,307 & 0,026
\end{tabular}

Sumber : Data diolah,2018

Berdasarkan Tabel 6 dapat dibuat persamaan regresi linier berganda sebagai berikut:

$$
\mathrm{Y}=-0,029-0,148 \mathrm{X}_{1}+0,330 \mathrm{X}_{2}-0,321 \mathrm{X}_{3}+0,223 \mathrm{X}_{4}+e .
$$

Nilai $\alpha$ sebesar $-0,029$ berarti jika $X_{1}, X_{2}, X_{3}$, dan $X_{4}$ bernilai konstan pada angka nol maka nilai $\mathrm{Y}$ akan turun 0,029 satuan. Koefisien regresi $\mathrm{X}_{1}$ yaitu $-0,148$ berarti jika $\mathrm{X}_{1}$ mengalami peningkatan sebesar satu satuan maka $\mathrm{Y}$ akan mengalami penurunan sebesar 0,148 satuan dengan asumsi variabel lainnya konstan. Koefisien regresi $\mathrm{X}_{2}$ yaitu 0,330 berarti jika $\mathrm{X}_{2}$ mengalami peningkatan sebesar satu satuan maka Y akan mengalami peningkatan sebesar 0,330 satuan dengan asumsi variabel lainnya konstan. Koefisien regresi $\mathrm{X}_{3}$ yaitu $-0,321$ berarti jika $\mathrm{X}_{3}$ mengalami peningkatan sebesar satu satuan maka $\mathrm{Y}$ akan mengalami penurunan sebesar 0,321 satuan dengan asumsi variabel lainnya konstan. Koefisien regresi $\mathrm{X}_{4}$ yaitu 0,223 berarti jika $\mathrm{X}_{4}$ mengalami peningkatan sebesar satu satuan maka Y akan mengalami peningkatan sebesar 0,223 satuan dengan asumsi variabel lainnya konstan. $e$ atau Error) dalam konsep statistika khususnya 
di dalam konsep regersi linier, error adalah semua hal yang mungkin memengaruhi variabel terikat $\mathrm{Y}$, yang mungkin tidak diamati oleh peneliti.

Uji kelayakan model (Uji F) digunakan sebagai alat analisis dalam menguji apakah semua variabel bebas yang diidentifikasi (profitabilitas, struktur aset, likuiditas, dan pertumbuhan penjualan) tepat digunakan memprediksi struktur modal. Adapun hasil dari pengujian kelayakan model dalam penelitian ini telah disajikan pada Tabel 7 berikut:

Tabel 7.

Hasil Uji Kelayakan Model (F)

\begin{tabular}{cccccc}
\hline Model & Sum of Squares & Df & Mean Square & F & Sig. \\
\hline Regression & 26,525 & 4 & 6,631 & 12,982 & $0,000^{\mathrm{a}}$ \\
Residual & 20,433 & 40 & 0,511 & & \\
Total & 46,958 & 44 & & &
\end{tabular}

Sumber: Data diolah,2018

Setelah melakukan uji $\mathrm{F}$ maka didapatkan hasil ahwa terdapat pengaruh yang signifikan antara $\mathrm{X}_{1}, \mathrm{X}_{2}, \mathrm{X}_{3}$, dan $\mathrm{X}_{4}$ terhadap $\mathrm{Y}$. hal ini dapat dilihat dari nilai $F_{\text {hitung }}$ yaitu 12,982 dan nilai sig. 0,000 yang kurang dari 0,05 , yang berarti kelompok yang diuji memiliki perbedaan yang nyata (signifikan).

Nilai dari adjusted $R$ square yang didapatkan adalah sebesar 0,521. Ini berarti variabel $\mathrm{X}_{1}, \mathrm{X}_{2}, \mathrm{X}_{3}$, dan $\mathrm{X}_{4}$ dapat mempengaruhi variabel $\mathrm{Y}$ secara signifikan sebanyak 52,10 persen sedangkan 47,90 persen sisanya dipengaruhi oleh variabel lain yang tidak digunakan pada persamaan dalam penelitian ini.

Uji t menunjukkan pengaruh variabel independen secara individu terhadap variabel dependen. Kriteria pengujian untuk menjelaskan interpretasi pengaruh antar variabel yakni apabila nilai signifikansi $<0,05$ maka $\mathrm{H}_{0}$ ditolak dan $\mathrm{H}_{1}$ diterima. Adapun hasil uji t disajikan pada tabel 8 sebagai berikut: 
Tabel 8.

Hasil Uji Hipotesis (Uji t)

\begin{tabular}{llccccc}
\hline Model & \multicolumn{2}{c}{ Unstandardized } & \multicolumn{2}{c}{ Standardized } & & \\
& & Coefficients & Coefficients & & \\
& & B & Std. Error & Beta & T & Sig. \\
\hline 1 & (Constant) & $-0,029$ & 0,108 & & $-0,268$ & 0,790 \\
& Profitabilitas $\left(\mathrm{X}_{1}\right)$ & $-0,148$ & 0,072 & $-0,220$ & $-2,057$ & 0,046 \\
& Struktur Aset $\left(\mathrm{X}_{2}\right)$ & 0,330 & 0,099 & 0,380 & 3,326 & 0,002 \\
& Likuiditas $\left(\mathrm{X}_{3}\right)$ & $-0,321$ & 0,117 & $-0,320$ & $-2,739$ & 0,009 \\
& Pertumbuhan penjualan $\left(\mathrm{X}_{4}\right)$ & 0,223 & 0,097 & 0,252 & 2,307 & 0,026 \\
\hline
\end{tabular}

Sumber: Data diolah,2018

Berdasarkan hasil uji parsial hipotesis pertama $\left(\mathrm{H}_{1}\right)$, nilai signifikansi yang dihasilkan adalah 0,046 dan Koefisien beta yang dihasilkan adalah -0,148. Hasil tersebut menunjukan bahwa profitabilitas $\left(\mathrm{X}_{1}\right)$ memiliki pengaruh yang negatif terhadap struktur modal (Y), yang berarti $\mathrm{H}_{1}$ dalam penelitian ini diterima. Hal ini berarti ketika terjadi peningkatan pada profitabilitas perusahaan maka akan berdampak pada turunnya struktur modal dari perusahaan. Perusahaan dengan tingkat profitabilitas tingi cenderung lebih menggunakan dana internalnya dibandingkan mencari pendanaan dari luar. Karena tingkat profitabilitas yang tinggi maka perusahaan memiliki lebih banyak dana internal oleh karena itu pendanaan eksternal hanya menjadi alternatif ketika dana internal dianggap tidak cukup untuk memenuhi pendanaan peusahaan.

Penelitian sebelumnya yang dilakukan oleh Çekrezi (2013), Mohamadzadeh et al. (2013), Alzomaia (2014), Gamaliel \& Sudjarni (2012), Sarlija \& Harc (2016), serta Dharmadi \& Putri (2018), menemukan hasil yang sama dengan penelitian ini. Pecking Order Theory mendukung hasil dari penelitian ini yaitu perusahaan lebih menggunakan dana internalnya terlebih dahulu daripada mencari dana eksternal (Brealey, Myers, \& Marcus, 2008). Dengan memiliki tingkat profitabilitas yang tinggi, perusahaan dikategorikan 
lebih mandiri jika dibandingkan dengan perusahaan yang memiliki tingkat profitabilitas yang rendah. Ketergantungan perusahaan dengan profitabilitas tinggi terhadap pihak eksternal terbilang cukup rendah karena perusahaan tersebut dapat menggunakan dana internalnya untuk mendanai perusahaannya (Dharmadi \& Putri, 2018).

Berdasarkan hasil uji parsial hipotesis kedua $\left(\mathrm{H}_{2}\right)$, nilai signifikansi yang dihasilkan adalah 0,002 dan Koefisien beta yang dihasilkan adalah 0,330. Hasil ini menunjukan struktur aset $\left(\mathrm{X}_{2}\right)$ memiliki pengaruh yang positif terhadap struktur modal (Y), yang berarti $\mathrm{H}_{2}$ dalam penelitian ini diterima. Hal ini berarti meningkatnya struktur aset perusahaan maka akan berdampak pada peningkatan struktur modal perusahaan. Perusahaaan dengan struktur aset yang tinggi atau memiliki aset tetap berwujud yang bernilai tinggi cenderung lebih mudah mendapatkan pendanaan dari eksternal. Hal ini karena aset tetap berwujud yang dimiliki oleh perusahaan tersebut dapat digunakan untuk mendapatkan pendanaan eksternal.

Suweta \& Dewi (2016), Pattweekongka (2014), Dharmadi \& Putri (2018), serta Liem (2013) dalam penelitian yang dilakukan juga menemukan bahwa bahwa struktur aset memiliki pengaruh positif terhadap struktur modal. trade-off theory merupakan teori yang mendukung hasil ini, menyatakan perusahaan yang mempunyai jumlah aset tetap yang terbilang tinggi, aset tersebut dapat dijadikan jaminan untuk melakukan pinjaman baru berupa hutang (Septiani \& Suaryana, 2018). Kreditur akan lebih yakin terhadap perusahaan yang mempunyai aset tetap yang besar karena apabila terjadi kegagalan pembayaran bayar maka perusahaan 
dapat menyelesaikan kewajibannya kepada kreditur dengan jaminan asetnya tersebut (Dharmadi \& Putri, 2018).

Berdasarkan hasil uji parsial hipotesis ketiga $\left(\mathrm{H}_{3}\right)$, nilai signifikansi yang dihasilkan yaitu 0,009 dan Koefisien beta yang dihasilkan adalah -0,321. Hasil ini menunjukan likuiditas $\left(\mathrm{X}_{3}\right)$ memiliki pengaruh negatif terhadap struktur modal (Y), yang berarti $\mathrm{H}_{3}$ dalam penelitian ini diterima. Hal ini berarti meningkatnya tingkat likuiditas perusahaan maka akan berdampak pada turunnya struktur modal perusahaan tersebut. Baiknya likuiditas dari sebuah perusahaan berdampak pada baiknya kemampuan perusahaan tersebut memenuhi kewajiban jangka pendek yang dimilikinya.

Hasil penelitian ini sejalan dengan penelitian yang dilakukan oleh Alom, (2013), Shanka (2015), Juliantika \& Dewi (2016), Marfuah \& Nurlaela (2017), dan Septiani \& Suaryana (2018) yang menunjukkan bahwa variabel likuiditas memiliki pengaruh negatif terhadap struktur modal. Didukung oleh pecking order theory yang menyatakan bahwa perusahaan yang memiliki tingkat likuiditas yang tinggi, cenderung akan menggunakan pendanaan internal dibanding pendanaan eksternal. Tingkat likuiditas yang baik yaitu baiknya kemampuan perusahaan dalam melunasi hutang-hutang yang dimiliki perusahaan, pelunasan hutang ini berdampak pada menurunnya tingkat hutang perusahaannya (Juliantika \& Dewi, 2016).

Berdasarkan hasil uji parsial hipotesis keempat $\left(\mathrm{H}_{4}\right)$, nilai signifikansi yang dihasilkan adalah 0,026 dan Koefisien beta yang dihasilkan adalah 0,223. Ditemukannyaa hubungan positif antara pertumbuhan penjualan dengan struktur 
modal (Y), yang berarti $\mathrm{H}_{4}$ dalam penelitian ini diterima. Hal ini berarti dengan adanya peningkatan pada pertumbuhan penjualan maka akan berdampak pada meningkatnya struktur modal dari perusahaan. Sesuai dengan Trade-off theory menjelaskan, pertimbangan perusahaan dalam memilih untuk menggunakan dana eksternal adalah dengan harapan bahwa manfaat yang didapatkan lebih besar dari utang yang diambil. Penggunaan dana eksternal berupa hutang adalah untuk membiayai operasional perusahaan. Peningkatan pada penjualan berarti akan adanya peningkatan pada volume produksi. Utang tersebut digunakan untuk membiayai peningkatan tersebut. Hasil penelitian ini sesuai dengan penelitian yang dilakukan oleh Khairin \& Harto (2014), Angelina \& Mustanda (2016), Erosvitha \& Wirawati (2016), dan Halim \& Widanaputra (2018).

Hasil penelitian ini mengonfirmasi teori pecking order dan teori trade-off dengan melihat profitabilitas, struktur aset, likuiditas dan pertumbuhan penjualan dalam mempengaruhi struktur modal. Hasil penelitian ini sejalan dengan teori pecking order dan teori trade-off, dimana teori pecking orders menjelaskan mengapa perusahaan dengan profit yang besar dan perusahaan dengan tingkat likuiditas yang tinggi umumnya mempunyai dana internal yang memadai dan sedikit menggunakan hutang. Trade-off theory menjelaskan mengapa perusahaan dengan aset tetap yang tinggi dan perusahaan yang pertumbuhan penjualnnya meningkat, cenderung akan meningkatkan kapasitas hutang untuk dapat menguntungkan perusahaan sehingga struktur modal perusahaan menjadi meningkat. 
Hasil penelitian ini juga diharapkan dapat memberikan tambahan ilmu pengetahuan, wawasan, dan menjadi referensi tambahan bagi penelitian selanjutnya yang berkaitan dengan struktur modal. Penelitian ini memberikan implikasi bagi investor sebagai bahan pertimbangan dan pengetahuan mengenai pengaruh profitabilitas, struktur aset, likuiditas, dan pertumbuhan penjualan pada struktur modal perusahaan makanan dan minuman yang terdaftar di Bursa Efek Indonesia. Hasil penelitian ini diharapkan dapat menjadi pertimbangan manajemen perusahaan dalam penyusunan suatu struktur modal yang optimal guna mengoptimalkan nilai perusahaan.

\section{SIMPULAN}

Profitabilitas berpengaruh negatif terhadap struktur modal. Hal ini berarti ketika terjadi peningkatan pada profitabilitas perusahaan maka akan berdampak pada turunnya struktur modal dari perusahaan. Perusahaan dengan tingkat profitabilitas tingi cenderung lebih menggunakan dana internalnya dibandingkan mencari pendanaan dari luar.

Struktur aset berpengaruh positif terhadap struktur modal. Hal ini berarti meningkatnya struktur aset perusahaan maka akan berdampak pada peningkatan struktur modal perusahaan.

Likuiditas berpengaruh negatif terhadap struktur modal. Hal ini berarti meningkatnya tingkat likuiditas perusahaan maka akan berdampak pada turunnya struktur modal perusahaan tersebut. 
Pertumbuhan penjualan berpengaruh positif terhadap struktur modal perusahaan. Hal ini berarti dengan adanya peningkatan pada pertumbuhan penjualan maka akan berdampak pada meningkatnya struktur modal dari perusahaan. Peningkatan pertumbuhan penjualan mengakibatkan perusahaan perlu penambahan modal agar mendukung pengembangan perusahaan.

\section{REFERENSI}

Acaravci, K. S. (2015). The Determinants Of Capital Structure: Evidence From The Turkish Manufacturing Sector. International Journal Of Economics And Financial Issues, 5(1).

Alom, K. (2013). Capital Structure Choice Of Bangladesh Firms: An Empirical Study. Asian Journal Of Finance \& Accounting, 5(1).

Alzomaia. (2014). Capital Structure Determinants Of Publicly Listed Companies In Saudi Arabia. Scholarly Journals.

Ambarwati, S. D. A. (2010). Manajemen Keuangan Lanjut. Yogyakarta.: Graha Ilmu.

Angelina, K. I. D., \& Mustanda, I. K. (2016). Pengaruh Penjualan Dan Profitabilitas Pada Struktur Modal Perusahaan. E-Jurnal Manajemen Unud, $5(3)$.

Bambang, R. (2013). Dasar-Dasar Pembelanjaan Perusahaan. (4th Ed.). Yogyakarta: Bpfe.

Brealey, R. A., Myers, S. C., \& Marcus, A. J. (2008). Fundamentals Of Corporate Finance. Sixth Edition. New York: Mc-Graw Hil.

Brigham, E. F., \& Housten, J. (2011). Dasar Dasar Manajemen Keuangan (11th Ed.). Jakarta: Salemba Empat.

Çekrezi, A. (2013). The Determinants Of Capital Structure: Evidence From Albania. Academic Journal Of Interdisciplinary Studies, 2(9), 370-376. Https://Doi.Org/10.5901/Ajis.2013.V2n9p370

Dharmadi, I. K. Y., \& Putri, I. G. A. M. A. D. (2018). Pengaruh Struktur Aset, Profitabilitas, Operating Leverage, Likuiditas Terhadap Struktur Modal Perusahaan Consumer Goods Di Bei. E-Jurnal Akuntansi Universitas 
Udayana, 24(3), 1858-1879.

Erosvitha, C. K. L., \& Wirawati., N. G. P. (2016). Pengaruh Profitabilitas, Set Kesempatan Investasi, Pertumbuhan Penjualan Dan Risiko Bisnis Pada Struktur Modal. E-Jurnal Akuntansi Universitas Udayana, 14(2).

Gamaliel, J., \& Sudjarni, L. K. (2012). Pengaruh Profitabilitas, Ukuran Perusahaan Dan Struktur Aktiva Terhadap Struktur Modal Pada Perusahaan Transportasi Di Bursa Efek Indonesia, 59-74.

Halim, P. M., \& Widanaputra, A. A. G. P. (2018). Pengaruh Ukuran Perusahaan, Pertumbuhan Penjualan Dan Risiko Bisnis Pada Struktur Modal. E-Jurnal Akuntansi Universitas Udayana, 23(3), 2391-2413.

Harahap, S. . (2016). Analisis Kritis Manajemen Keuangan.Jakarta: Pt Raja Grafindo Persada.

Husnan, S., Hanafi, M. M., \& Munandar, M. (2014). Price Stabilization And Ipo Underpricing: An Empirical Study In The Indonesian Stock Exchange. Journal Of Indonesian Economy And Business: Jieb, 29(2).

Juliantika, N. L. A. A. M., \& Dewi, M. R. (2016). Pengaruh Profitabilitas, Ukuran Perusahaan, Likuiditas, Dan Risiko Bisnis Terhadap Struktur Modal Pada Perusahaan Property Dan Realestate, 5(7), 4161-4192.

Kanita, G. G. (2014). Pengaruh Struktur Aktiva Dan Profitabilitas Terhadap Struktur Modal Perusahaan Makanan Dan Minuman. Jurnal Ilmu \& Riset Akuntansi, 13(2), 127-135. Https://Doi.Org/10.1002/Anie.200460442

Kasmir. (2010). Pengantar Manajemen Keuangan. (1st Ed.). Jakarta: Kencana Khairin.

Kennedy, Et Al. (2010). Faktor-Faktor Yang Mempengaruhi Struktur Modal Pada Perusahaan Real Estate And Property Yang Go Public Di Bursa Efek Indonesia. Jurnal Ekonomi Universitas Riau.

Khairin, M. Y., \& Harto, P. (2014). Pengaruh Growth Opportunity, Profitabilitas, Fixed Asset Ratio Dan Risiko Pasar Terhadap Struktur Modal. Diponegoro Journal Of Accounting, 3(2).

Liem, J. H. (2013). Faktor-Faktor Yang Mempengaruhi Struktur Modal Pada Industri Consumer Good Yang Terdaftar Di Bei Periode 2007-2011. Jurnal Ilmiah Mahasiswa Universitas Surabaya, 2(1), 1-11.

Mamduh, M. H. (2008). Manajemen Keuangan (1st Ed.). Yogyakarta.: Bpfe. 
Mardinawati. (2011). Faktor-Faktor Yang Memepengaruhi Struktur Modal Pada Perusahaan Otomotif Yang Terdaftar Di Bursa Efek Indonesia. Jurnal Administrasi Bisnis, 12(3), 1-10.

Marfuah, S. A., \& Nurlaela, S. (2017). Pengaruh Ukuran Perusahaan , Pertumbuhan Aset, Profitabilitas Dan Pertumbuhan Penjualan Terhadap Struktur Modal Perusahaan Cosmetic And Household Di Bursa Efek Indonesia. Jurnal Akuntansi Dan Pajak, 18(1).

Masnoon, Maryam., \& Abiha, S. (2014). Capital Structure Determinants Of Kse Listed Automobile Companies. European Scientific Journal, 10(13), 451461.

Moeljadi, \& Supriyati., T. S. (2014). Factors Affecting Firm Value: Theoretical Study On Public Manufacturing Firms In Indonesia. South East Asia Journal Of Contemporary Business, Economics And Law, 5(2).

Mohamadzadeh, M., Arabi, S. M., \& Salamzadeh., J. (2013). Organizational Perfomance, Marketing Strategy, And Financial Strategic Aligment: An Empirical Study On Iranian Pharmaceutical Firms. Daru Journal Of Pharmaceutical Sciences.

Munawir. (2008). Analisis Laporan Keuangan (3rd Ed.). Jakarta: Banyu Media Abadi.

Nofriani, I. (2015). Pengaruh Profitabilitas, Ukuran Perusahaan, Pertumbuhan Penjualan, Pertumbuhan Aset, Dan Likuiditas Terhadap Struktur Modal. Tanjungpinang: Universitas Maritim Raja Ali Haji.

Pattweekongka, S. Dan K. N. (2014). Determinants Of Capital Structure: Evidence From Thai Lodging Companies. International Journal Of Arts \& Sciences, 7(4), 45-52.

Puspawardhani, N. (2011). Pengaruh Pertumbuhan Penjualan, Profitabilitas, Struktur Aktiva Dan Ukuran Perusahaan Terhadap Struktur Modal Pada Perusahaan Pariwisata Dan Perhotelan Di Bei, 2050-2065.

Ryanni, M. L., \& Farah, M. (2014). Faktor-Faktor Yang Mempengaruhi Struktur Modal Pada Perusahaan Manufaktur Yang Terdaftar Di Bursa Efek Indonesia. Jurnal Manajemen. Fakultas Ekonomi Universitas Trisakti.

Saleem, F., Rafique, B., Mehmood, Q., Irfan, M., Saleem, R., Tariq, S., \& Akram, G. (2013). The Determination Of Capital Structure Of Oil And Gas Firms Listed On Karachi Stock Exchange In Pakistan. Interdisciplinary Journal Of Contemporary Research In Business, 4(9). 
Sarlija, N., \& Harc, M. (2016). Capital Structure Of Small And Medium Enterprises In Crostia. Managing Global Transitions, 14 (3), Pp: 251-266. Sartono, .

Sartono, A. (2012). Manajemen Keuangan Teori Dan Aplikasi (4th Ed.). Yogyakarta.: Bpfe.

Septiani, N. P. N., \& Suaryana, I. G. N. A. (2018). Pengaruh Profitabilitas, Ukuran Perusahaan, Struktur Aset, Risiko Bisnis Dan Likuiditas Pada Struktur Modal. E-Jurnal Akuntansi Universitas Udayana, 22(3), 16821710 .

Shanka., P. B. And D. (2015). Determinants Of Capital Structure Of Indian Firms: A Study Of Bse 500 Companies. International Recognized Double-Blind Peer Reviewed Multidisciplinary Research Journal.

Sitanggang, J. P. (2013). Manajemen Keuangan Perusahaan Lanjutan. (1st Ed.). Jakarta: Mitra Wacana Media.

Suweta, N. M. N. P. D., \& Dewi, M. R. (2016). Pengaruh Pertumbuhan Perjualan, Struktur Aktiva, Dan Pertumbuhan Aktiva Terhadap Struktur Modal. EJurnal Manajemen Unud, 5(8), 5172-5199. Https://Doi.Org/Issn : 2302-8912

Udayani, D., \& Suaryana, I. G. N. A. (2013). Pengaruh Profitabilitas Dan Investment Opportunity Set Pada Struktur Modal. E-Journal Akuntansi Udayana, 2(1), 299-314.

Weston, J. F., \& Copeland., T. E. (2008). Dasar-Dasar Manajemen Keuangan. Jakarta: Erlangga.

Wiagustini, N. L. P. (2014). Manajemen Keuangan. Denpasar: Udayana University Press.

Wijaya, I. P. A. S., \& Utama., I. M. K. (2014). Pengaruh Profitabilitas, Struktur Aset, Dan Pertumbuhan Penjualan Terhadap Struktur Modal. E-Jurnal Akuntansi Unud, 6(3).

Windayu, C. R. (2016). Factors Affecting The Capital Structure In Textile And Garment Listed In Indonesia Stock Exchange. Iosr Journal Of Business And Management, 8(10). 